\title{
Scientific Initiation in Professional and Technological Education: Conceptions and Guidelines
}

\author{
Carlos Henrique Marchiori ${ }^{\uparrow}$
}

1 Ins tituto Federal Goiano

Scientific initiation is a type of academic research developed by undergraduate students in Brazilian universities in various areas of knowledge.

\section{PROGRAM INSTITUTIONAL PURSE OF SCIENTIFIC RESEARCH}

Lecture given to students of the Federal Institute of Goiano

Items covered:

Program $\rightarrow$ Written with details on some subject. Example - project.

Institutional $\rightarrow$ developed by an institution (teaching, research, etc.). To owe.

Scholarship $\rightarrow$ Free remuneration (student - artist - teacher). It is an instrument of development.

\section{1-SCIENTIFIC RESEARCH}

a - Research projects - Plan - initiative (method - technique). Method $\rightarrow$ T eaching

Technique (thorough).

Technique $\rightarrow$ Practice.

b-Scientific work

c-Report writing

d- Presentation of results in events

e-Prepare the individual for graduate -labor market.

\section{2-THESE ARE THE HIGH SCHOOL PROGRAMS THAT THE PUBLIC SCHOOL CAN} PARTICIPATE IN:

IC / OBMEP - In conjunction with the Institute of Pure and Applied Mathematics, the Brazilian Public Schools Mathematics Olympics are promoted and their winners receive CNPq scholarships to further their studies.

PIBIC-EM - In partnership with universities to guide high school students in public schools. 
IC-Jr - Junior Scientific Initiation is carried out in partnership with the Research Support Foundations ( http://cnpq.br/iniciacao-cientifica).

\section{3-THE SCIENTIFIC INITIATION PROGRAMS THAT CNPQ DEVELOPS WITH THE} INSTITUTIONS ARE:

PIBIC - The Institutional Program for Scientific Initiation Scholarships serves public and private institutions. You need to find a teacher who can guide you in your area of interest. PIBIC-Af - The Institutional Program of Scientific Initiation Scholarships in Affirmative Actions is directed only to public institutions and students who entered Higher Education through affirmative action.

PIBITI - The Institutional Program of Initiation Scholarships in Technological Development and Scientific Innovation serves public and private institutions, however, it is directed only to the technological and innovation areas.

PICME - The Scientific Initiation and Masters Program is aimed at the winners of the Brazilian Public School Mathematics Olympiad who wish to deepen their knowledge in mathematics.( http://cnpq.br/iniciacao-cientifica).

\section{4-OBJECTIVES OF THE PROGRAM}

a-Awakening scientific vocation and encouraging new potential talents among undergraduate students.

b-Provide the institution with a research initiation policy formulation instrument for students.

c-Provide the scholarship holder, guided by a qualified researcher, the learning of research techniques and methods, as well as stimulate the development of scientific thinking and creativity, resulting from the conditions created by the direct confrontation with the research problems.

\section{5-UNDERGRADUATE SUBJECTS FOR SCIENTIFIC RESEARCH:}

a- Scientific Methodology (subject-object relationship in scientific research - the formation of the scientific spirit - relationship theory and practice in the production of scientific knowledge).

b- Methods and Techniques of Scientific Research (types of research b- the research project - work presentation structure - report).

Note: short time (4 months) and sometimes student disinterest $\rightarrow$ Does not prepare the student well. 